\title{
EVALUATION OF THE FREQUENCY OF PREMENSTRUAL SYNDROME MANIFESTATIONS IN THE POPULATION OF GENERATIVE WOMEN
}

\author{
Milena Marjanović ${ }^{1}$, Nikola Savić ${ }^{2,3}$, Zoran Jokić ${ }^{3,4}$, Svetlana Vukosavljević ${ }^{5}$ \\ 1. Valjevo Health Center \\ 2. Medical school "Dr Miša Pantić" Valjevo \\ 3. Faculty of Health and Business Studies Valjevo, Singidunum University \\ 4. Polyclinic Jokić Valjevo \\ 5. Kosjerić Health Center
}

Osoba za korespondenciju:

BSc Milena Marjanović

adresa: Železnička 12, 14000 Valjevo, Srbija

E-mail: lenny.marjanovic@gmail.com;

Tel: +381658069749

Proces prihvatanja/Article history:
Primljen/Received 21.08.2021.
Revidiran/Received in revised form
Prihvaćen/Accepted 29.09.2021.

\section{EVALUACIA UČESTALOSTI MANIFESTACIJA PREDMENSTRUALNOG SINDROMA U POPULACIJI ŽENA GENERATIVNOG DOBA SAŽETAK}

Uvod: Tokom predmenstrualnog sindroma javlja se niz fizičkih i psiholoških manifestacija u lutealnoj fazi menstruacionog ciklusa. Predmenstrualni sindrom je poremećaj u reproduktivnom dobu koji negativno utiče na kvalitet života žene. Cilj rada je procena učestalosti manifestacija predmenstrualnog sindroma u populaciji žena generativnog doba.

Materijal i metode: Istraživanje je sprovedeno u vidu studije preseka kao instrument istraživanja, konstruisan je upitnik za žene generativnog doba, kojim se procenjuje njihov stepen informisanosti o predmenstrualnom sindromu, simptomima predmenstrualnog sindroma, načinu ublažavanja simptoma i uticaju na kvalitet života. Ispitivanjem je obuhvaćen uzorak od 260 ispitanica, studija je sprovedena u Domu zdravlja u Valjevu u vremenskom periodu od novembra 2020. godine do februara 2021. godine. Učešće u studiji je bilo dobrovoljno i anonimno.

Rezultati: U analizi rezultata korišćene su metode deskriptivne statistike. Ispitanice su starosti od 18 do 44 godina. Većinom su iz gradske sredine $(66,7 \%)$ sa završenom srednjom školom $(66,7 \%)$, u radnom odnosu (91,7\%), u braku (58,3\%). Većina ispitanica ima neke od simptoma predmenstrualnog sindroma, dok manji procenat negira simptome. Značajan podatak je da $50 \%$ žena smatra da stresne situacije pogoršavaju simptome. Veliki broj žena je informisan o predmenstrualnom sindromu (91,7\%), veliki broj žena (75\%) se nije obratilo lekaru zbog tegoba i veliki broj ne koristi nikakvu terapiju (83,3\%).

Zaključak: Žene u reproduktivnom dobu su u velikom broju izložene predmenstrualnom sindromu. Svi simptomi ovog sindroma utiču na kvalitet života, radnu sposobnost i odnose u porodici, na svakodnevno funkcionisanje. Efikasna primena zdravstvenovaspitnih intervencija iz oblasti reproduktivnog zdravlja predstavlja osnovnu meru u poboljšanju kvaliteta života žena sa predmenstrualnim sindromom, kao i prevenciji ili eliminaciji problema zdravlja.

Ključne reči: predmenstrualni sindrom, menstrualni ciklus, reproduktivno doba.

\begin{abstract}
Introduction: During the premenstrual syndrome, many physical and psychological manifestations occur in the luteal phase of the menstrual cycle. Premenstrual syndrome is a disorder in the reproductive age that negatively affects a woman's quality of life. The aim of this study was to estimate the frequency of manifestations of premenstrual syndrome in the population of women of generative age.
\end{abstract}

Material and methods: The research was conducted in the form of a cross-sectional study, a research instrument, was constructed questionnaire, for women of childbearing age, which assesses their level of information about premenstrual syndrome, premenstrual syndrome symptoms, symptom relief and quality of life. The study included a sample of 260 respondents, the study was conducted at the Health Center in Valjevo in the period from November 2020 to February 2021. Participation in the study was voluntary and anonymous.

Results: Descriptive statistics methods were used in the analysis of the results. The respondents are between 18 and 44 years old. Most of them are from urban areas $(66.7 \%)$ with completed high school (66.7\%), employed (91.7\%), married (58.3\%). Most respondents have some of the symptoms of premenstrual syndrome, while a smaller percentage deny the symptoms. An important fact is that $50 \%$ of women think that stressful situations worsen their symptoms. A large number of women were informed about premenstrual syndrome (91.7\%), a large number of women $(75 \%)$ did not consult a doctor due to problems and a large number did not use any therapy (83.3\%).

Conclusion: Women of reproductive age are highly exposed to premenstrual syndrome. All the symptoms of this syndrome affect the quality of life, work ability and family relations, and daily functioning. Effective implementation of health education interventions related to reproductive health is a basic measure to improve the quality of life of women with premenstrual syndrome, as well as to prevent or eliminate health problems.

Key words: premenstrual syndrome, menstrual cycle, reproductive age. 


\section{INTRODUCTION}

The menstrual cycle can be affected by a number of factors, including age, ethnicity, family history, smoking, physical activity, and eating habits. Stress can be a major contributor or cause of menstrual problems [1]. Premenstrual syndrome is associated with the menstrual cycle, especially with the luteal phase of the menstrual cycle, and disappears with menstruation [2]. Hippocrates was the first to introduce a connection between menstruation and behavioral changes. Robert Frank, an American doctor from the Medical Academy in New York, attributed these changes in ovarian dysfunction in 1931 and used the terminology "premenstrual tension" [3]. Premenstrual syndrome It is a wide range of physiological and psychological symptoms that occur in the luteal phase of the menstrual cycle and that pass during or immediately after the onset of menstruation. The asymptomatic interval between the end of menstruation and the time of ovulation is important in order to exclude other disorders. The diagnosis can be made only in the presence of ovulation. The diagnosis is confirmed by a symptom diary, which is kept for a minimum of two cycles [4]. Premenstrual syndrome is a common untreated disorder and public health problem, among women of reproductive age, that negatively affects mental health, quality of life and social performance [3]. Numerous scientific studies indicate that premenstrual syndrome is closely related to mood disorders, through the regulation of estrogen and serotonin [5]. Symptoms are divided into two categories: physical and psychological, and premenstrual syndrome can be considered a periodic recurrence of a combination of disruptive, physical, psychological and behavioral changes during the luteal phase of the menstrual cycle that interferes with life activities [6]. Physical symptoms include breast tenderness, bloating, abdominal pain, weight gain, edema, headache, back pain, nausea, bowel movements, acne, and psychiatric symptoms including irritability, anxiety, nervousness, depression, excessive fatigue and weakness, confusion, confusion. moods, sleep patterns and appetites. Studies have also shown that adolescents with premenstrual syndrome have lower health potential [6]. Mild premenstrual syndrome is characterized by up to three physical or emotional symptoms, which women sometimes do not perceive as premenstrual syndrome. The most severe form of premenstrual syndrome, premenstrual dysphoric disorder (PMDD), is characterized by more serious symptoms associated with psychological manifestations and intense mood swings [7].
About $50 \%$ to $80 \%$ of women of reproductive age have some symptoms of premenstrual syndrome, and about $3 \%$ to $8 \%$ will experience extreme mood swings, which interfere with their lifestyle and can be severe enough to lower their self-esteem as well as affect their school and work attendance [7]. More than $90 \%$ of women have premenstrual syndrome in their reproductive years. A scientific study conducted in Iran, between 2009. and 2011. years, shows a prevalence of premenstrual syndrome of $52 \%$, of which $34 \%$ suffer from a more severe form [8]. Premenstrual syndrome affects the quality of sleep and rest in a large number of cases [9]. Menstrual migraine (MM) and premenstrual syndrome (PMS) are two conditions associated with certain phases of the menstrual cycle. The exact pathophysiological mechanisms are not fully understood, but both conditions are thought to be triggered by female hormones [10]. No association of this syndrome with the age of onset of the first menstruation and the duration of the cycle was observed. However, it has been found to be associated with bleeding during menstruation and the presence of dysmenorrhea [11]. The main purpose of treating premenstrual syndrome is to alleviate the symptoms and reduce its effects on daily routine activities. Pharmacotherapy has always been the first line of treatment for premenstrual syndrome, but recent research suggests superior benefits of combination therapy [12]. Premenstrual symptoms should be monitored prospectively for at least two consecutive menstrual cycles using a diary, as retrospective data are unreliable $[13,14]$. The combination of pharmacotherapy and non-pharmacological treatments, cognitive and behavioral therapy, exercises with massage therapy, light therapy, with diet modification have proven to be useful in treatment. It is recommended to correct the lifestyle by regular exercise, avoiding stress, maintaining healthy habits, regular sleep during the menstrual cycle. Untreated premenstrual syndrome is likely to affect sex life, leading to higher levels of sexual distress, which in turn can lead to relationship problems and more psychological problems $[15,16]$. Premenstrual syndrome has a negative impact on women's relationships with their partners and children, as well as on household chores [17, 18]. Premenstrual syndrome is more common among white women, smokers, obese and young women [19]. Physicians need to adjust therapy to achieve the greatest possible functional improvement for their patients. The education of women is very important and the patient family $[20,21]$. 


\section{MATERIAL AND METHODS}

The research was conducted in the form of a cross-sectional study. As a research instrument, a questionnaire for women of childbearing age was constructed to assess the frequency of manifestations of premenstrual syndrome. The study included a sample of 260 women, the study was conducted at the Valjevo Health Center in the period from November 2020 to February 2021. The sample of respondents included in the research study is intentional, in the observed sample were the users of health care at the Valjevo Health Center. Participation in the study was voluntary and anonymous, the research was approved by the competent authorities of the institution. Criteria for inclusion of respondents in the study is personal consent to participate in the survey and consent to provide answers to all questions from the questionnaire. The criterion for non-inclusion of the respon- dents is that they did not want to participate in the research and that they did not have an adequate number of years. The criterion for excluding the respondents from the research is their desire not to give an answer to all the questions from the questionnaire. Prior to the start of the research, the respondents received the necessary information regarding the study itself orally and in writing. Respondents were given instructions with the correct completion of the questionnaire. The questionnaires were distributed and data collected personally by the researchers. Statistical data processing includes methods of descriptive statistics. The obtained results are presented in absolute numbers and percentages.

\section{RESEARCH RESULTS}

The first five questions in the survey refer to the sociodemographic characteristics of the respondents (Table 1).

Table 1. Socio-demographic structure of the respondents

\begin{tabular}{l|l|l|l}
\hline \multicolumn{1}{l|}{ Criteria for the distribution of respondents } & $\mathbf{N}$ & \% \\
\hline \multirow{2}{*}{ Age } & $18-25$ & 22 & $8 \%$ \\
\cline { 2 - 4 } & $26-35$ & 108 & $42 \%$ \\
\cline { 2 - 4 } & $36-44$ & 130 & $50 \%$ \\
\hline \multirow{2}{*}{ Place of living } & Urban environment & 172 & $66 \%$ \\
\cline { 2 - 4 } & Rural environment & 88 & $34 \%$ \\
\hline \multirow{2}{*}{ Educational level } & Primary and Secondary school & 175 & $67 \%$ \\
\cline { 2 - 4 } & $\begin{array}{l}\text { Vocational and Academic } \\
\text { studies }\end{array}$ & 85 & $33 \%$ \\
\hline \multirow{2}{*}{ Marriage status } & Employed & 240 & $92 \%$ \\
\cline { 2 - 4 } & Unemployed & 20 & $8 \%$ \\
\hline & Married & 150 & $58 \%$ \\
\cline { 2 - 4 } & Divorced & 10 & $4 \%$ \\
\cline { 2 - 4 } & Unmarried & 55 & $21 \%$ \\
\cline { 2 - 4 } & Extramarital union & 45 & $17 \%$ \\
\hline
\end{tabular}


Table 2. Informing women about the symptoms of premenstrual syndrome, the presence and frequency of symptoms, contacting health professionals and the use of therapy.

\begin{tabular}{|c|c|c|c|}
\hline \multicolumn{2}{|c|}{ Criteria for the distribution of respondents } & \multirow{2}{*}{$\begin{array}{l}\mathbf{N} \\
175\end{array}$} & \multirow{2}{*}{\begin{tabular}{|l|}
$\%$ \\
$67 \%$ \\
\end{tabular}} \\
\hline Symptoms & The presence of symptoms & & \\
\hline & Absence of symptoms & 85 & $33 \%$ \\
\hline \multirow[t]{3}{*}{ Number of symptoms present } & One symptom & 34 & $13 \%$ \\
\hline & More than one symptom & 120 & $46 \%$ \\
\hline & No symptoms & 106 & $41 \%$ \\
\hline \multirow{2}{*}{$\begin{array}{l}\text { Symptoms in two consecutive } \\
\text { menstrual cycles }\end{array}$} & Yes & 185 & $71 \%$ \\
\hline & Not & 75 & $29 \%$ \\
\hline \multirow[t]{2}{*}{ Worsening under stress } & Yes & 130 & $50 \%$ \\
\hline & Not & 130 & $50 \%$ \\
\hline \multirow{2}{*}{$\begin{array}{l}\text { Awareness of the onset of } \\
\text { premenstrual syndrome }\end{array}$} & Recognition of manifestations & 240 & $92 \%$ \\
\hline & Uninformed women & 20 & $8 \%$ \\
\hline \multirow{2}{*}{$\begin{array}{l}\text { Consultation with a doctor due } \\
\text { to discomfort }\end{array}$} & Yes & 65 & $25 . \%$ \\
\hline & Not & 195 & $75 \%$ \\
\hline \multirow{2}{*}{$\begin{array}{l}\text { Using therapy to alleviate } \\
\text { discomfort }\end{array}$} & Yes & 44 & $17 \%$ \\
\hline & Not & 216 & $83 \%$ \\
\hline \multirow[t]{3}{*}{ Frequency of symptoms } & Every month & 65 & $25 \%$ \\
\hline & Periodically & 151 & $58 \%$ \\
\hline & Never & 44 & $17 \%$ \\
\hline
\end{tabular}

Table 3. Assessment of the severity of problems and their impact on quality of life and daily activities on the Likert scale (from $1-5$ ).

\begin{tabular}{l|l|l|l}
\hline \multicolumn{1}{l}{ Criteria for the distribution of respondents } & $\mathbf{N}$ & $\mathbf{\%}$ \\
\hline \multirow{4}{*}{$\begin{array}{l}\text { Assessment of the severity of } \\
\text { the problem }\end{array}$} & $\mathbf{2}$ & 34 & $13 \%$ \\
\cline { 2 - 4 } & $\mathbf{3}$ & 34 & $13 \%$ \\
\cline { 2 - 4 } & $\mathbf{4}$ & 120 & $46 \%$ \\
\cline { 2 - 4 } & $\mathbf{5}$ & 65 & $25 \%$ \\
\hline \multirow{4}{*}{$\begin{array}{l}\text { The impact of premenstrual } \\
\text { syndrome symptoms on quality } \\
\text { of life }\end{array}$} & $\mathbf{2}$ & 11 & $3 \%$ \\
\cline { 2 - 4 } & $\mathbf{3}$ & 44 & $17 \%$ \\
\cline { 2 - 4 } & $\mathbf{5}$ & 130 & $20 \%$ \\
\cline { 2 - 4 } & $\mathbf{5}$ & 34 & $50 \%$ \\
\hline
\end{tabular}




\section{DISCUSSION}

The first part of the survey contains data related to demography. According to the topic, $100 \%$ of the surveyed participants are women. Women aged 3644 years make up half of the respondents (50\%), 2635 years $(42 \%)$ and $18-25$ years (8\%). Out of a total of 260 respondents, the population from urban areas is $66 \%$ of respondents, while $34 \%$ are from rural areas. In terms of education, twice as many women have completed high school (67\%), while 33\% have a university degree. The dominant percentage of persons is employed (92\%), the percentage of non-employed persons is $8 \%$. The largest number of surveyed women are married (58\%), unmarried (21\%), $17 \%$ live in an extramarital union and $4 \%$ are divorced. Among the premenstrual symptoms in one of the questions, we singled out: painful breast tenderness, bloating, abdominal pain, weight gain, edema, headache, back pain, nausea, acne, bowel movements or constipation. The majority of respondents $(67 \%)$ have some of these symptoms, while $33 \%$ of women deny the presence of these symptoms.

Irritability, anxiety, nervousness, depression, excessive fatigue and weakness, confusion, mood swings, changes in sleep patterns and appetite are listed as symptoms that occur 5-7 days before the menstrual cycle and last until the fourth day of the cycle. One third (41\%) stated that they did not feel any of these symptoms, that $13 \%$ had one of these symptoms and that $46 \%$ had more than one offered symptom.

According to the offered symptoms individually, the percentages look like this:

Irritability - 37\%

Anxiety - 20\%

Nervousness - $42 \%$

Depression - 4\%

Excessive fatigue and weakness - 21\%

Confusion - 0\%

Mood swings - $46 \%$

Sleep and appetite change $30 \%$

More than $71 \%$ of women experienced symptoms of this syndrome in two menstrual cycles, while $29 \%$ had them in only one cycle. A significant data in the study is that $50 \%$ of respondents believe that stressful situations worsen these symptoms, while $50 \%$ do not. A high percentage of $92 \%$ were informed about the premenstrual symptom, while $8 \%$ had not yet heard of premenstrual symptoms. Based on the presented data, so far $75 \%$ of women have not consulted a doctor due to problems, and only a quarter of $25 \%$ have. More than $83 \%$ of respondents do not use any therapy to alleviate the discomfort. A much smaller proportion of respondents $17 \%$ use some of the therapies. Some of the problems are experienced by $25 \%$ of the surveyed women every month, $58 \%$ have occasional problems, while $17 \%$ have no problems at all. At the end of the research, we offered the respondents to rate their premenstrual problems on a scale of 1-5. We would like to single out the fact that the middle of the scale, number 3 , was chosen by as many as $46 \%$, while $25 \%$ chose number 4 , number 1 and 2 by $13 \%$ and number 5 only $3 \%$. This is the best indicator of the presence of premenstrual syndrome. Also, we offered a question to mark the impact of problems on the quality of life and daily activities on a scale of 1-5. Number 1 was chosen by $17 \%$ of respondents, number $2-20 \%$, number 3 - $50 \%$ of respondents and number $4-13 \%$. None of the respondents decided to circle the number 5 . The results of our research are similar to the data obtained in numerous international scientific studies of a similar character [10-21].

\section{CONCLUSION}

The conducted research showed that the presence of premenstrual syndrome is the highest among women aged 36 to 44 years. A large number of respondents are insufficiently informed and encouraged to seek help from health workers. Of great importance is health - educational work, consultations with health workers and the availability of gynecological health care.

\section{DECLARATION}

In the research, we adhered to the methods of scientific research and respected ethical aspects. There is no conflict of interest among the authors. 


\section{REFERENCES}

1. Rafique N, Al-Sheikh M. Prevalence of menstrual problems and their association with psychological stress in young female students studying health sciences. Saudi Med J. 2018;39(1):67-73.

2. Liu Q, Wang Y, van Heck C. Stress reactivity and emotion in premenstrual syndrome. Neuropsychiatr Dis Treat. 2017;13:1597-602.

3. Direkvand-Moghadam A, Sayehmiri K, Delpisheh A, Sattar K. Epidemiology of Premenstrual Syndrome (PMS)-A Systematic Review and Meta-Analysis Study. J Clin Diagn Res. 2014;8(2):106-9.

4. Appleton SM. Premenstrual Syndrome: Evidence-based Evaluation and Treatment. Clin Obstet Gynecol. 2018 Mar;61(1):52-61.

5. Sumarni S, Hidayat S, Pujonarko D. The Effect of Premenstrual Exercise on PMS Score, Perceived Stress Score, Body Image Score, and Cortisol Level for Premenstrual Syndrome. International Journal of Psychosocial Rehabilitation. 2020;24(SI 1):1131-43.

6. Rad M, Sabzevary MT, Dehnavi ZM. Factors associated with premenstrual syndrome in Female High School Students. J Educ Health Promot. 2018;7:64.

7. Nogueira C, Pinto e Silva J. Prevalência dos Sintomas da SíndromePré-Menstrual. Rev Bras de Ginecol e Obstet. 2000;22(6):347-51.

8. Nazari N, Birashk B, Ghasemzadeh A. Effects of group counseling with cognitive-behavioral approach on reducing psychological symptoms of Premenstrual syndrome (PMS). Procedia - Social and Behavioral Sciences. 2012;31:589-92.

9. Eggert L, Kleinstäuber M, Hiller W, Witthöft M. Emotional interference and attentional processing in premenstrual syndrome. J Behav Ther Exp Psychiatry. 2017;54:77-87.

10. Vetvik KG, MacGregor EA, Lundqvist C, Russell MB. Symptoms of premenstrual syndrome in female migraineurs with and without menstrual migraine. J Headache Pain. 2018;19(1):97.

11. Sarkar A, Mandal R, Ghorai S. Premenstrual syndrome among adolescent girl students in a rural school of West Bengal, India. International Journal of Medical Science and Public Health. 2016;5(4):773-6.

12. Jehan S, Auguste E, Hussain M, Pandi-Perumal SR, Brzezinski A, Gupta R, et al. Sleep and Premenstrual Syndrome. J Sleep Med Disord. 2016;3(5):1061.

13. Mikacich J. Premenstrual Disorders. Postgraduate Obstetrics \& Gynecology. 2008;28(24):1-5.

14. Özmermer T, Koruk F. Premenstrual syndrome frequency, premenstrual syndrome coping strategies and factors affecting premenstrual syndrome in university students in Turkey. LIFE: International Journal of Health and Life-Sciences. 2019;4(3):138-55.

15. Durairaj A, Ramamurthi R. Prevalence, pattern and predictors of premenstrual syndrome (PMS) and premenstrual dysphoric disorder (PMDD) among college girls. The New Indian Journal of OBGYN. 2019;5(2):93-8.

16. Hsiao MC, Liu CY, Chen KC, Hsieh TT. Characteristics of women seeking treatment for premenstrual syndrome in Taiwan. Acta Psychiatr Scand. 2002;106(2):150-5.

17. Mohib A, Zafar A, Najam A, Tanveer H, Rehman R. Premenstrual Syndrome: existence, knowledge, and attitude among female university students in Karachi. Cureus. 2018; 10(3): e2290.

18. Panahi F, Faramarzi M. The Effects of mindfulness-based cognitive therapy on depression and anxiety in women with premenstrual syndrome. Depress Res Treat. 2016;2016:9816481.

19. Jeong I. Premenstrual Syndrome and Exercise: Prospect of Further Research. Journal of Sport and Leisure Studies. 2012;48:973-80.

20. Van Leusden HA. Premenstrual syndrome no progesterone; premenstrual dysphoric disorder no serotonin deficiency. Lancet. 1995;346(8988):1443-4.

21. Coughlin PC. Premenstrual syndrome: how marital satisfaction and role choice affect symptom severity. Soc Work. 1990;35(4):351-5. 